\title{
Representations of the Life-giving Spring feast in Romanian iconography
}

\begin{tabular}{|c|c|}
\hline $\begin{array}{l}\text { Author: } \\
\text { loan O. Abruo }\end{array}$ & $\mathrm{n}^{1,2}$ \\
\hline $\begin{array}{l}\text { Affiliations: } \\
\text { }{ }^{2} \text { Department } \\
\text { Theology, Fac } \\
\text { Theology, Luci } \\
\text { University of } \\
\text { Sibiu, Romani }\end{array}$ & $\begin{array}{l}\text { f Orthodox } \\
\text { lty of } \\
\text { an Blaga } \\
\text { ibiu, }\end{array}$ \\
\hline $\begin{array}{l}{ }^{2} \text { Department } \\
\text { and Historical } \\
\text { Faculty of The } \\
\text { Religion, Univ } \\
\text { Pretoria, Pret } \\
\text { South Africa }\end{array}$ & $\begin{array}{l}\text { f Systematic } \\
\text { Theology, } \\
\text { ology and } \\
\text { ersity of } \\
\text { oria, }\end{array}$ \\
\hline $\begin{array}{l}\text { Research Proj } \\
\text { Project Leade } \\
\text { Project Numb }\end{array}$ & $\begin{array}{l}\text { ect Registration: } \\
\text { r: J. Pillay @ } \\
\text { er: } 04653484\end{array}$ \\
\hline $\begin{array}{l}\text { Description: } \\
\text { The author is } F \\
\text { the research a } \\
\text { Prof. Dr Jerry P } \\
\text { Theology and } \\
\text { University of P }\end{array}$ & $\begin{array}{l}\text { articipating as } \\
\text { ssociate of Dean } \\
\text { illay, Faculty of } \\
\text { Religion, } \\
\text { retoria. }\end{array}$ \\
\hline $\begin{array}{l}\text { Correspondin } \\
\text { loan Abrudan, } \\
\text { abrudanioano } \\
\text { com }\end{array}$ & $\begin{array}{l}\text { g author: } \\
\text { vidiu@yahoo. }\end{array}$ \\
\hline $\begin{array}{l}\text { Dates: } \\
\text { Received: } 08 \text { A } \\
\text { Accepted: } 30 \\
\text { Published: } 30\end{array}$ & $\begin{array}{l}\text { pr. } 2021 \\
\text { uly } 2021 \\
\text { Sept. } 2021\end{array}$ \\
\hline $\begin{array}{l}\text { How to cite th } \\
\text { Abrudan, I.O., } \\
\text { 'Representatic } \\
\text { Life-giving Spr } \\
\text { Romanian icor } \\
\text { HTS Teologies } \\
\text { Theological St } \\
77(4) \text {, a6719. } \\
\text { org/10.4102/ }\end{array}$ & $\begin{array}{l}\text { is article: } \\
2021, \\
\text { ons of the } \\
\text { ing feast in } \\
\text { ography', } \\
\text { e Studies/ } \\
\text { udies } \\
\text { https://doi. } \\
\text { tts.v77i4.6719 }\end{array}$ \\
\hline $\begin{array}{l}\text { Copyright: } \\
\text { ( 2021. The A } \\
\text { Licensee: AOS } \\
\text { is licensed unc } \\
\text { Creative Comr } \\
\text { Attribution Lic }\end{array}$ & $\begin{array}{l}\text { uthors. } \\
\text { IS. This work } \\
\text { der the } \\
\text { nons } \\
\text { ense. }\end{array}$ \\
\hline Read online: & \\
\hline 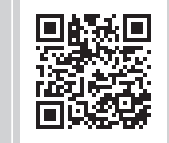 & $\begin{array}{l}\text { Scan this QR } \\
\text { code with your } \\
\text { smart phone or } \\
\text { mobile device } \\
\text { to read online. }\end{array}$ \\
\hline
\end{tabular}

\section{Author:}

Affiliations

${ }^{1}$ Department of Orthodox

University of Sibiu

${ }^{2}$ Department of Systematic and Historical Theology, Faculty of Theology and Pretoria, Pretoria,

Research Project Registration: Project Leader: J. Pillay (D

Description: Prof. Dr Jerry Pillay, Faculty of Theology and Religion,

\section{Corresponding author:}

oan Abrudan,

abrudanioanovidiu@yahoo.

Dates:

Received: 08

Accepted: 30 July 2021

Published: 30 Sept. 2021

brudan, I.O., 2021

Life-giving Spring feast in

Romanian iconography',

HTS Teologiese Studies

Copyright:

Licensee: AOSIS. This work

is licensed under the

Creative Commons

Attribution License.

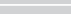

This article explores the development of the theme of the Life-giving Spring in Byzantine iconography. The path towards its establishment was initiated at the moment when a representation rule, an original convention was set. Thereafter, because of its diffusion in time and space, the theme became enriched by particular mentalities and sensibilities of the epochs and the communities that adopted it as a form of devotion for the Virgin Theotokos. As a result, the representations we have known so far are extremely varied.

Contribution: The final purpose of this approach, as well as its contribution, is to highlight the diverse unity of the iconographic tradition and illustrate both the evolution of the theme in the painting of Romanian church artists and its gradual refinement through the incorporation of diverse nuances and new perspectives.

Keywords: Life-giving Spring; Byzantine and post-Byzantine iconography; ancient Romanian art; woodcut; goldsmith.

\section{Introduction}

The theme of the Life-giving Spring was adopted at a late time in the Byzantine iconographic repertoire. It is an illustration of the homonymous feast dedicated to Virgin Mary, which is celebrated, in Orthodox churches, on the Friday of the Bright Week.

When instituting this feast in the first decade of the 14th century, the Church consecrated an almost millennial cult that had developed as an expression for the piety of the countless pilgrims who came from different parts of the empire to visit a stream of water, considered to have healing properties, springing in a grove of cypress trees outside the walls of Constantinople. At that place, near the gate of the city that the Byzantines called 'the Gate of the Spring', and later the Ottomans called Silivria (Runciman 1971:107), Emperor Justinian I founded, in the 6th century, a monastery dedicated to Our Lady, which included a church and a fountain fed by the 'life-giving spring' - Zoodochos Pighi ('H Z

The Byzantine artists who established the canon of iconographic representation of the feast found their inspiration in two sources. In a first instance, it was agreed to exploit the popularity enjoyed by the fountain existing in the crypt of the church of Theotokos Zoodochos Pighi monastery in Constantinople, a destination often visited by pilgrims.

The second source was the service, composed in honour of the feast, which could have provided the painters with many picturesque details and, through them, with the opportunity to enrich the iconographic composition and confer it the value of proof for the incessant miracles occurring at the spring of the Mother of God. The late reception, not earlier than the 18th century, of the text of this service in the synaxaria of the churches where Slavonic was the language used during the service made the original formula persist in the practice of iconographers. This situation was characteristic of the church painters in the Romanian provinces. Only the revival, during the 18th century, of the cult dedicated to the spring of Constantinople, by the resumption of pilgrimages and the restoration of the foundation of the church of the monastery destroyed by the Ottomans in the 15th century, led to the emergence of a new type of feast icon, which was encountered mainly in Serbia, Bulgaria (Lubanska 2017:5) and the Romanian countries. The composition, which used to focus on the image of

Note: Special Collection: Lucian Blaga University, Sibiu, Romania, sub-edited by Daniel Buda (Lucian Blaga University) and Jerry Pillay (University of Pretoria). 
the Virgin and the Child in a praying attitude, was animated by the introduction of the multitude of characters who rush towards the healing spring.

\section{Representations of the feast dedicated to the Mother of God - The Source of Life in the Byzantine iconographic tradition}

A number of studies on Byzantine art, published over the last decades, have reconstructed the history of one of the most frequented monasteries in Constantinople. They have also focussed on the presentation of the oldest testimonies about, on the one hand, the Life-giving Spring and the legends that circulated about the sick who were healed by drinking and washing with its waters, and, on the other hand, about the cult that developed in connection with the attribution of these blessings to divine power and the intercession of the Blessed Virgin.

Among the oldest sources that substantiated this historical reconstruction, the primacy belongs to the writing De Aedificiis, by Procopius of Caesarea (c. 500-c. 565) (eds. Hauri \& Wirth 1963:20-21). The chronicler recorded the circumstances in which the monastery was founded by Emperor Justinian the Great, who built it from the surplus materials used on the site of the Hagia Sophia church. Procopius also points out that the church surpassed in monumentality all the other sanctuaries dedicated to the Blessed Virgin, the emperor seeking to plant and establish in this way in Byzantium the veneration enjoyed by the Mother of God in the Holy Land (Belting 1994:35).

An anonymous author of the 10th century listed the series of miraculous healings that took place at the 'divine and Life-giving spring of the Virgin', as they had been recorded in hagiographic writings, beginning with the middle of the 5th century, during the reign of the emperor Leo I (457-474) and until the end of the 9th century. On account of so many pious testimonies, he expressed his conviction that the 'shrine could be considered an inexhaustible source of miracles and healings, which occur continuously, or rather incessantly, since both grace and divine power overshadows the place' (Constantinou 2021:326). According to the same unknown author, as it had fallen into ruin because of its antiquity, the church of Justinian was rebuilt from the foundations by Emperor Basil I (865-886) (Mango 1972:103).

Nikephoros Kallistos Xanthopoulos (c. 1265-c. 1335) worked in a similar way at the beginning of the 14th century rewriting the 10th century florilegium and updating it by recording 16 other miraculous healings that took place in the meanwhile. If the author of the anonymous writing had been concerned mainly with highlighting the miracles that benefitted emperors or members of their families, and who instead undertook works of building, restoring or beautifying the church of the monastery of Our Lady,
Xanthopoulos widens the circle of those who enjoyed the beneficial effect of ayazma. The new miracles, presented by Xanthopoulos:

$[H]$ ave protagonists from different backgrounds suffering from various diseases. The sufferers of the fourteenth century thus belong to all social classes: the upper (members of the imperial family, the aristocracy and the high ecclesiastical ranks), the middle (merchants and soldiers), the lower (priests, anonymous poor and women) and even and from the margins of society (prostitutes). They also come from a number of places: Constantinople, Sparta, Serres, Nicaea and from an island in the Black Sea. As for their suffering, the author mentioned various diseases such as leprosy, anthrax and rash, cancer, dropsy, kidney stones and asthma. (Constantinou 2021:338)

The effort to compile an exhaustive collection of testimonies about the miraculous properties of the spring was also carefully grounded, because the author made use of only credible sources, identified from historical periods and from very diverse places. Undoubtedly, such an approach served the process of establishing a feast day dedicated to 'the Spring of Life'. The composition of Akolouthia, that is, the canon of the service of this feast, was attributed to Xanthopoulos. He is also the one who left us an expressive description of the fountain in the church crypt.

The monastery of Our Lady of the spring was granted, in 1329, the status of stavropegial, and in 1332 it became the metochion of the Great Lavra from Mount Athos. Thus, its fame could spread both from the Byzantine capital and by way of Athos. An important contribution to facilitating this dissemination was made by pilgrims who came to Constantinople from everywhere, including Russia (Majeska 1984:325).

The establishment of the holiday and the composition of the service that were celebrated on the Friday of the Bright Week determined the establishment of an iconographic canon, therefore of a convention for the representation of that subject. The issue of the emergence and the spread of the original iconic model corresponding to the feast were analysed by Tatjana Starodubcev (Starodubcev 2009:101-119), who manages to identify, based on recent research, six of the earliest images of this type that have been preserved, dating back to the 14th century. They are found in churches in Mistra, Constantinople, in the Serbian churches of Lesnovo and Ravanica, and in Russia, in Volotovo, near Novgorod.

The limited level of reception of Akolouthia in those parts of Eastern Orthodoxy where the liturgical ritual was not celebrated in Greek lacked, as I have pointed out above, a direct and immediate influence of the service in forming a specific image of the Mother of God with the Infant. Of the icons studied, only those belonging to churches within the borders of the Byzantine Empire, such as those at Mistra (Church of the Virgin Aphendico) and Constantinople 


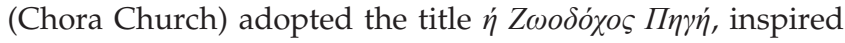
by the service composed by Xanthopoulos.

A comparison of the oldest icons of the feast reveals that, in all cases, the Virgin is represented in a praying attitude and, with one exception (Ravanica), the figuration of the fountain, which allows one to admit that the production of the original iconographic model was under the influence of the representation in mosaic of the Mother of God, possibly of the Blachernitissa type, found on the vault of the crypt arranged around the basin of the Pighi Monastery, a decoration completed during the reign of Emperor Andronikos II the Palaeologus (1282-1328) (Teteriatnikov 2005:225). The phenomenon described by Xanthopoulos, which involved the reflection of the icon in the clear water of the fountain, should have been, undoubtedly, extremely impressive (Buda 2018:183) for pious pilgrims. It was interpreted by iconographers and led to its establishment in the canon of representation consecrated by the Byzantine tradition.

\section{The theme Theotokos Zoodochos Pighi in the mural painting of the Romanian Principalities from the late medieval period}

During the late Middle Ages and in the pre-modern period, the Virgin as Source of Life is found only sporadically in church painting in Romanian Principalities. The earliest example is the presentation of the theme in the soffit of the arch that supports to the north the vault of the narthex in the church 'St. Nicholas' from Popăuţi, in Botoşani County (Ştefănescu 1929:140). It is part of the original iconographic programme of the church, which was painted inside in 1496, immediately after its construction (Ulea 1964:426; Ullea 2012:160) by the ruler of Moldavia, Stephen the Great.

It appears, in the same iconographic variant, as part of the ample composition with the theme The Tree of Jesse, painted next to the tomb room, on the south facade of the church from Moldoviţa (Ştefănescu 1929:159-160). The church was consecrated by the ruler Petru Rareş in 1531, whose exterior frescoes were completed in 1537 (Ullea 2012:169).

In the second half of the same century, one can identify it for the first and only time in the original version - The Virgin as Spring of Life - in Wallachia, inside the church of Tismana monastery (Dumitrescu 1973:263). The interior paintings of the church, and the work of the painter Dobromir from Târgovişte, were the gifts from the great vornic Nedelco Bălăceanu, from 1564 (Dumitrescu 1978:19, 59, 60). The scene is positioned similarly to the location occupied in the church from Popăuţi, namely on the tympanum of the door that opens in the north wall of the narthex.
The function of that ritual room, especially in the case of monastic churches, was primarily funerary:

$[B]$ oth because the founders and donors were buried here, and because of the provisions of the norms that had established, ever since the fourteenth century, that the services of remembrance of the dead were to be officiated in that space. (Dumitrescu 1973:267, 268)

'In the liturgy of Saint Basil the Great, immediately after the epiclesis, the priest says the secret prayer of intercession: he prays for those who passed away' (Ştefănescu 1929:139), while the axion, 'Rejoice', composed by St. John of Damascus (addressed to the Blessed Virgin) is sung at the pew (Vintilescu 2006:95; Farcaşiu 2008:63).

The icon reappears in Romanian painting only after the middle of the 17th century, in hypostases inspired by both iconographic formulas representing the feast. In Moldavia, at the Cetăţuia monastery, near Iaşi, the icon of the Virgin as Spring of Life was painted, in 1673, by Aromanian craftsmen, from Ioannina. The scene is placed in the narthex, in the northern arcosolium, where the founder tombs are sheltered. Against the background of the walls of Constantinople, the praying Mother of God and the Infant at her breast are placed at the end of a flared cup-shaped column with an octagonal lip. A multitude of people hurry to drink from the gushing water and gather in the pool from which the column rises (Ştefănescu 1929:61). This painting represents the first attestation in the Romanian iconography of the theme transposed in a developed compositional scheme, being of course an import that was mediated by the painters from Epirus. An aspect also present in this case is the investment of the image with a funerary function, as the tomb above which the Source of Life icon was painted was initially prepared for Mrs. Anastasia, the wife of voivode Gheorghe Duca, the two being the main founders of the monastery.

Towards the end of the century, the subject was approached, in two situations, by the painters hired, starting from 1693 to 1694 (Iancovescu 2008a:45), to make mural decorations in the monastic complex from Hurezi, in Vâlcea County, the largest settlement of this kind in Wallachia, founded by Prince Constantin Brancoveanu. In the first case, the image, in the concentrated version, accompanied by the name $\dot{\eta} \zeta \omega 0 \delta$ ó $\chi \varsigma$ $\pi \eta \gamma \eta$, was placed in the niche of the prothesis of the big church, in the vicinity of the inscription in which the team of painters were mentioned, led by the group coordinators, Constantin and Ioan. There had been a precedent for placing the image with this subject in the altar space (Ştefănescu 1932:186), but not in the proscomidaire, but in the diaconicon, a situation reported by Gabriel Millet at the church 'Saints Theodores' in Mistra (Millet 1910:128). In Hurezi, the presence of the Spring of Life in the niche of the proscomidaire:

$[I]$ s remarkable, not only for the interest shown now for this theme, but also for the natural way in which it is integrated in a new space, respectively in front of the table, along with the painted inscription of the diptych, included in a passage referring to the source of immortality, from the first prayer of proskomedia. (Iancovescu 2008b:48) 


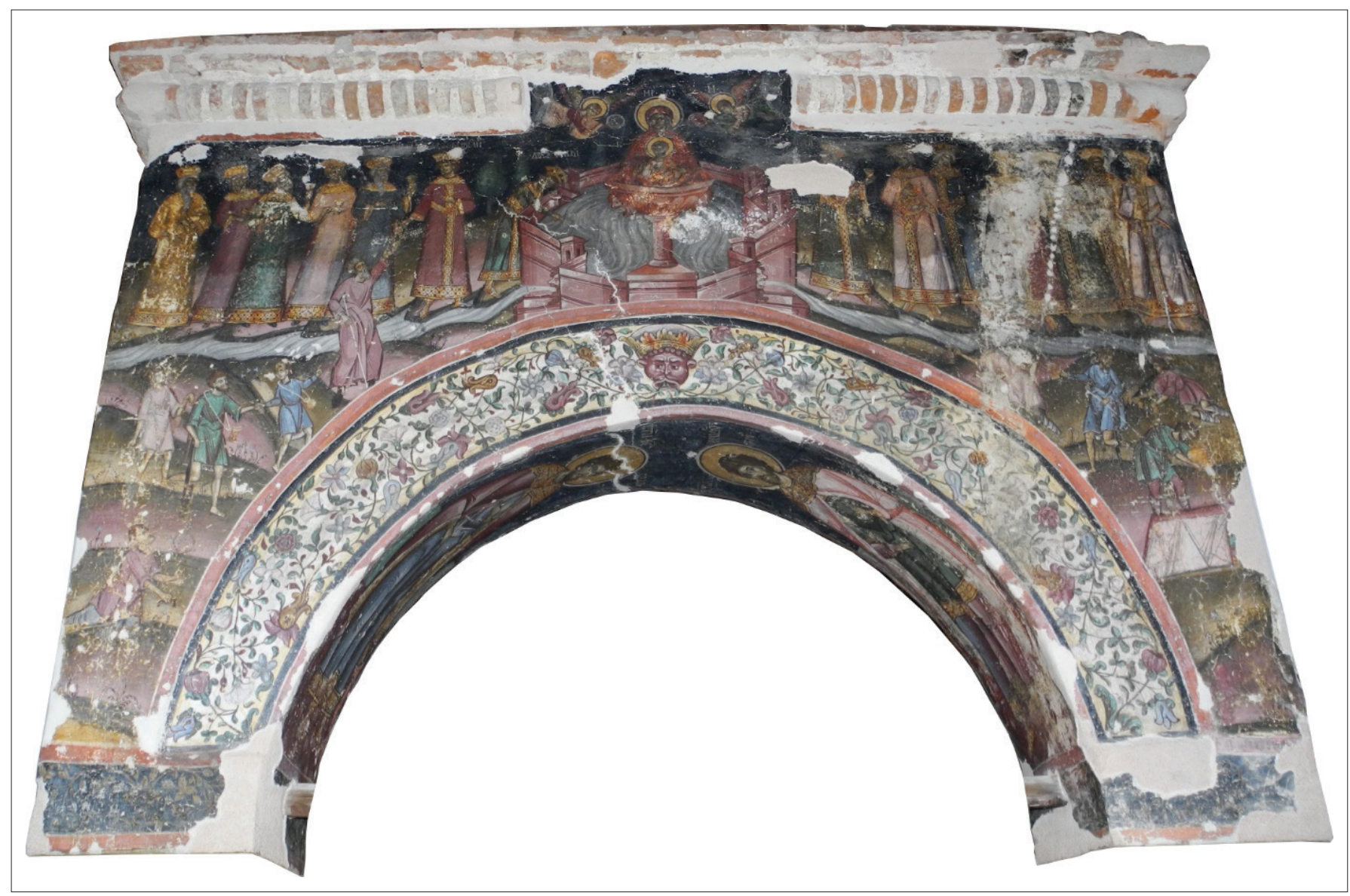

FIGURE 1: The fountain of the Hurezi Monastery.

Attached to the eastern wall of the main enclosure, displaying a specific aedicula architecture (Figure 1), the monastery fountain was decorated with paintings by the same team of artists, between 1692 and 1697, or in the first years after 1700 (Vasiliu 1991:20). 'A brief iconography' was conceived in relation to it, 'whose selection and placement makes a discourse on Orthodox dogma and mysticism starting from the theme of water and spring ... to the high spiritual meaning of the monks' (Vasiliu 1991:20). The repertoire of paintings includes the following compositions: on the dome, the image of the Burning bush, surrounded by the representation of the Heavenly Jerusalem; some feasts of the Church are represented on the pendants, where the same theme of water or fountain is evoked (the Sunday of Samaritan, the Sunday of the Blind, the Sunday of the Paralytic); on the arches, the military martyrs and the ascetics are depicted, and on the outside, on all three sides of the kiosk, 'the consecrated image of the Virgin Zoodochos Pighi, represented frontally and framed by rows of characters and convincing acts of mercy' (Vasiliu 1991:21), which indicates the source that inspired the craftsmen - the Synaxarium text from Bright Friday.

Among the other monuments of the Brancovan period, the theme 'The source of life' also appears, in the concise, 'abstract-allegorical' transposition, on the southern façade of the church of Govora monastery, a representation probably completed in 1711-1712 (Iancovescu 2008c:350, 353, 357).

\section{Theme Theotokos Zoodochos Pighi in Romanian portable icons from the 18th century}

Consecrated as a theme of the Brancovan art, The Lifegiving Spring became a favourite subject for church painters in the second half of the 18th century, invariably occupying a position in the narthex of churches, on the eastern tympanum (Cojocaru 2015:170).

During the same period, the subject began to be recorded in the thematic repertoire of portable icons. For Wallachia, we can mention two such situations. First of all, it is present in the work of an artist who signed, in 1737, with the formula 'The humble Theodor, painter from Megalovlahia (Wallachia), Bucharest', a set of eight icons, including a feast icon, with the illustration of the Healing Spring. Those icons were intended for the iconostasis in the chapel dedicated to the feast mentioned above, from the Spilia monastery, in Karditsa (a city in the region of Thessaly, Greece) (Cândea 2011:709). The painter was originally from Aghia, near Larissa (Tsiouris 2013:20), and was one of the Greek artists who settled in the Romanian Lands.

In Bucharest, in the Colţea church, there is an icon of the Mother of God with the Child, covered in silver. At the bottom of the ridge, under the right hand of the Virgin, the theme $\dot{\eta} \zeta \omega o \delta$ ó $0 \varsigma \pi \eta \gamma \dot{\eta}$ was represented. Figure 2, whose 


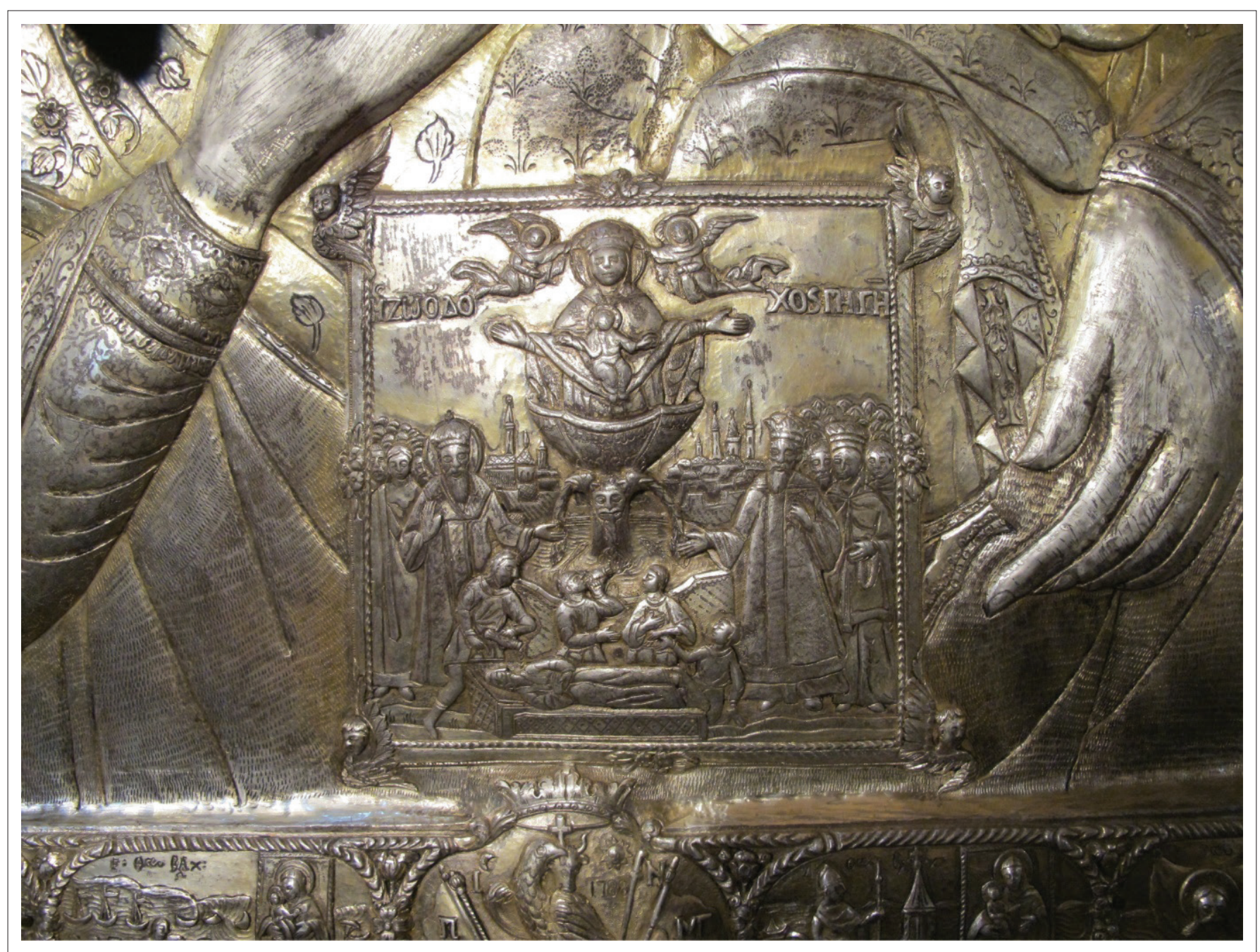

FIGURE 2: Colţea Church, Bucharest. Icon of Virgin Mary - Hodegetria (detail).

painting dates from the late 17th century, however, comes from the church of the former monastery the Life-giving Spring - Mavrogheni. It was donated to this monastic settlement in Bucharest in 1787, on which occasion, in 1788, the founder also ordered the beautiful piece of goldsmith's work in which it was placed (Buzilă 2010:14).

Prince Nicolae Petru Mavrogheni (1786-1790) nurtured a true cult for fountains and gardens. The spring near the monastery erected by him fed both a flowing fountain, placed under the protection of 'Mother of God and everlasting Virgin', and a 'water treasury', that is, the main reservoir from which water was captured and distributed through clay pots to the entire network of taps established by the ruler in Bucharest (Dinioară 2020:4, 5). And it was not the only place where Mavrogheni cultivated this passion. Originally from the Greek island of Paros, in the Cycladic archipelago, Mavrogheni showed his generosity towards the monasteries in his homeland, including the one near Naoussa, dedicated to Zoodochos Pighi. Right in the centre of the capital Parikia, where the house of the Mavrogheni family was located:

[T]here are three fountains built (in 1777) by Nicholas, whose name is beautifully carved in stone, and on the outskirts of the town stands the Byzantine monastery Ekatontapyliani, rectified and richly endowed by Nicolae Mavrogheni with art objects and important sums of money from Wallachia. (Cândea \& Simionescu 1982:78)

Among the donations made to the church were the silver shields intended, in 1777, to adorn the royal icons. On the cover of the icon Panagia Ekatontapyliani the Life-giving Spring is represented in a formula similar to the one used by the silversmith who covered the icon from the edifice founded by Mavrogheni in Bucharest. But in terms of artistic technique, the piece from Wallachia is much more elaborate and seems to correspond rather to the manner in which the ridge of the Pantocrator from Ekatontapyliani was performed. Even if, in terms of their production, these two works are more than a decade apart, they seem to come from the same workshop, possibly from Transylvania.

\section{Illustration of Theotokos Zoodochos Pighi in 18th-century Transylvanian cult books}

In the 18th century, the book of the Pentekostarion was translated into Romanian, which includes the order of the services that are read and sung in the Holy Churches of 
the East, beginning with the Holy and bright Day of Easter to the Sunday of All Saints'. The book was translated from Slavonic, but the text was corrected and completed by its confrontation with the Greek version of the book. Thus, although it was not in accordance with the tradition, the translators included in the Romanian editions 'the canon of the Mother of God, whose verse ... in Greek is ... belongs to Nichifor Callist from Xantopol'. The Akolouthia was available to believers and even church painters because the earliest Slavonic translation of the Pentecost by the scholar Damaschin Dascălul, bishop of Râmnic (1708-1725), printed in the diocese's hometown, in 1743 and simultaneously in Bucharest, by Metropolitan Neophyte of Wallachia.

In the foreword of the Pentekostarion printed in Blaj, in 1768, the Romanian translator informed his readers that 'we had striven to follow the oldest Greek manuscript', and thus he asked them not to blame him if they 'found in that Pentekostarion ... something added, which in the Romanian and Slavonic documents printed up to that point, was not found ...'. And indeed, among the mentioned additions from that first Romanian edition printed in Transylvania, one could identify the service from 'Bright Friday, of The Lifegiving Spring, of Our Most Holy Lady the Mother of God'.

It is therefore no coincidence that, in Transylvania, the first iconographic representations of the feast, attested at the earliest in the last quarter of the 18th century, there are woodcuts from the pages of ritual books, printed in the church typographies of Blaj and Sibiu, belonging to the two Christian confessions of the Eastern rite - Greek Catholic and Orthodox.

Following the icons of the feast in the order in which the above-mentioned books were printed, they are found in the Book of Akathists published in 1774, in Blaj (p. 422), in the typography of the monastery of the Annunciation (Mircea 2008:210), in the Horologion (Romanian: Ceaslov) printed in the same workshop in 1786 (p. 552), then in four books printed with the blessing of the Orthodox bishops of Transylvania, in the printing house owned in Sibiu by Petrus Barth and later by his son, Johann Andreas Barth: The Horologion from 1790 (p. 567), The Psalter (shown in Figure 3) from 1791 (p. 226), the Greek and Romanian Catavasier from 1803 (p. 2) and the Psalter from 1825 (p. 270).

A common feature of these books is the association, by no means accidental, between the illustration of the Life-giving Spring and the introduction in their contents of the Service of the small Paraklesis to the Most Holy Theotokos, respectively of the Katavasia of the Nativity. The service dedicated to the Virgin Theotokos is the small canon of prayer, composed in the 9th century by Theosterictus the Monk, which invokes ( $\pi \alpha \rho \alpha \dot{\kappa} \wedge \lambda \eta \sigma 1 \varsigma$ meaning 'to call') the intercession and help of the Mother of God, as 'it is sung at moments of abomination (sorrow) of the soul and in time of need'.

The six images, which are completely similar, were printed in each case on the page preceding the text of the respective Paraklesis, or of the Katavasia. The presentation of the scene is

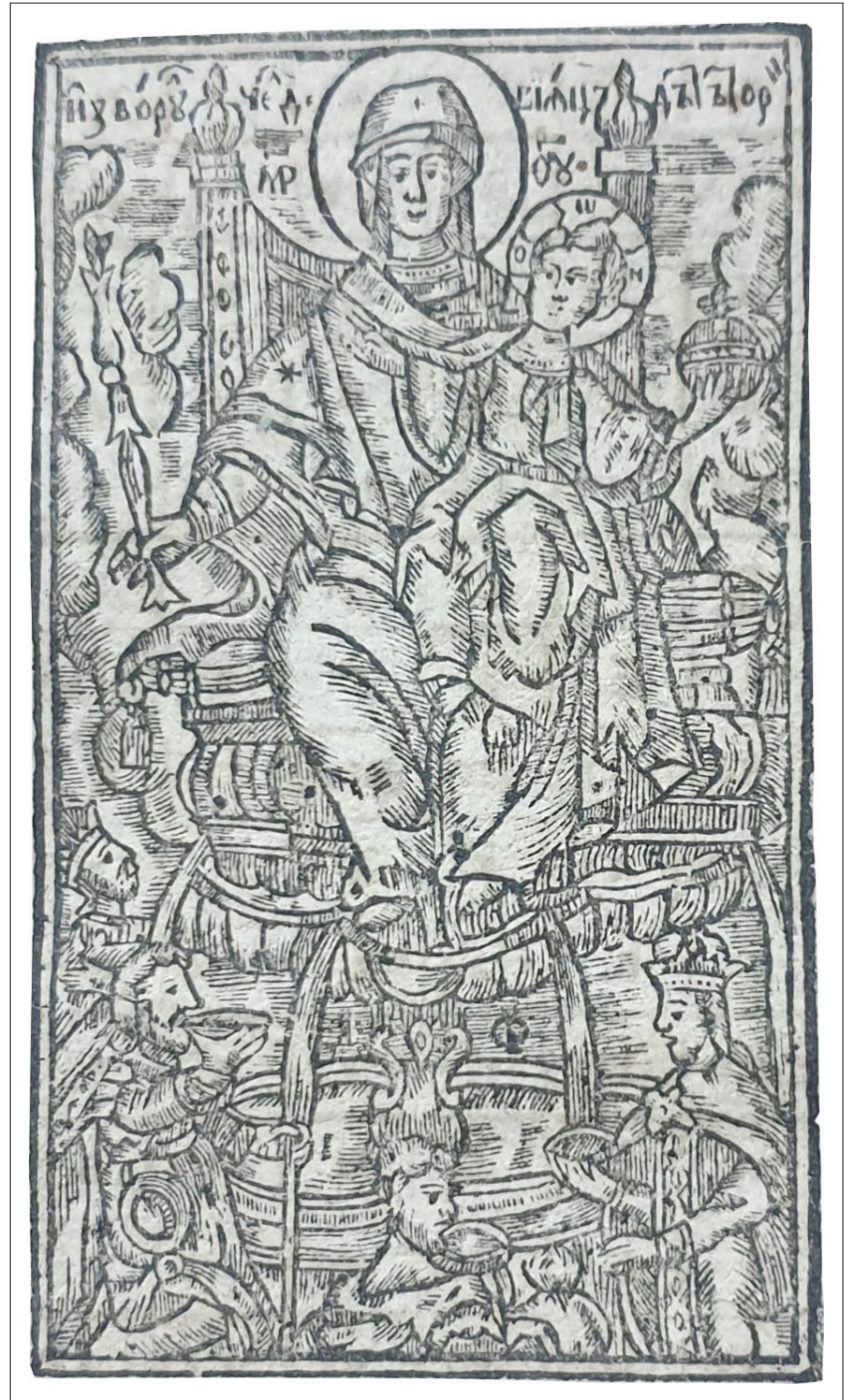

FIGURE 3: Woodcut from the Psalter of Sibiu (1791).

concise. In the upper register, which occupies two-thirds of the surface of the engraving, the Mother of God with the Infant dominates the entire composition from the height of the cup of a well, from which water flows into a basin. Around them, four characters, two emperors and two pilgrims, filled their glasses to drink from the water of the healing spring.

The source that inspired this representation seems to have been an engraving printed in Vienna, in 1744 or 1745, by Hristofor Zefarovic. Interpreted by the Serbian artist in the manner of Western Baroque aesthetics, the image circulated and was frequently copied at the time (Brisby 2003:30-45; Lubanska 2017:5). Elements that distinguish Zefarovic's composition could have also been adopted by Romanian engravers. Very similar aspects, such as the attitude of the Virgin and of the Infant sitting on her left knee, the monarchical insignia (the sceptre associated with the Mother of God and the Globus cruciger of Jesus) and the attitude and details of clothing of the pilgrim in the foreground justify this assumption.

As hieromonk and artist, with preoccupations in various fields, such as mural painting, printing and book illustration, 
embroidery or liturgical goldsmithing, Hristofor Zefarovic enjoyed a fame that reached the Romanian countries as well. The National Museum of Art of Romania includes a rich collection of embroidered vestments and liturgical veils that were ordered to Hristofor Zefarovic in Vienna by the descendants of Prince Constantin Brâncoveanu or by the Metropolitan of Ungrovlahia, Neofit Cretanul.

The woodcut from the Book of Akhatists from Blaj, the oldest of those of the Life-giving Spring that was printed in Transylvania, bears the signature of Petru Papavici. As part of the activity he conducted between 1764 and 1782 in the printing house in Blaj, where he held the position of first printer for a long time, Papavici made at least 42 original engravings, mostly signed with his name (Mircea 2008:211), or also including the nickname of Râmniceanu, which attests his origin in that region in northern Oltenia.

The same pattern, used for printing the illustration from the Book of Akhatists, served at its reprinting in the Ceaslov of Blaj, from 1786 (Mircea 2008:281). The model of representation that Papavici consecrated in the Transylvanian iconography was mastered by one of the craftsmen who were in his entourage in Blaj, Dimitrie Finta. In 1790, two engravings with the initial D.F., one of which was the Life-giving Spring, appeared in the Ceaslov from Sibiu (Tatai-Baltă 1995:123; Mircea 2008:299, 300) with reprints in the Psalters from Sibiu, of 1791 and 1825, but also in the Catavasier from 1803.

At the turn of the 18th and 19th centuries, the theme also had transpositions in the genre of monumental painting in Transylvania. One such example is the fresco painted on a spring crucifix, an aedicule erected on the edge of the village of Răşinari, near Sibiu. The function of the monument, customised by the choice of the iconographic subject, was to consecrate on a spiritual plan for the flow of the nearby stream. The inscription in the field of the image mentions the name of Pop Ioan Zugravul and the date 20 August 1795.

The icon represents the figures of the 'Our Lady of Mercy' and of the Infant, emerging from the cup of a fountain. Groups of people suffering from diseases, such as blindness, head towards that fountain to glorify Jesus and His Mother. The inscription that outlines the icon indicates the source that inspired the painter, namely the synaxarium of the feast 'The Source of the Most Holy Mother of God', which intercedes, in a wonderful way, the healing from 'erysipelas and leprosy, from yellow colds and blindness'. As nephew of one of the painters from Hurezi, from the time of Constantin Brâncoveanu, Ioan was undoubtedly familiar with the painting of the fountain at the monastery, with its rich composition that could have inspired him as well.

The medieval church 'St. Gheorghe' from Lupşa village (Alba County) was extended at the beginning of the 19th century. On the occasion of those renewals, more precisely in the period 1810-1811, the apse, the iconostasis and the narthex were repainted. On the eastern wall of the narthex, a large composition depicting the Mother of God, the source of healing, bears the signature of the painters Simion Silaghi from Abrud and Nicolae Ciungar (Porumb 1998:213). The painting indicates undoubtedly the adoption of the model consecrated in the Transylvanian iconography by the printing of the woodcut of Petru Papavici from Blaj.

After the middle of the 19th century, the developed formula for representing the feast became widespread - with a very lively and picturesque composition, employing considerable characters, just as they are identified in the synaxarium as described by the popular Byzantine church painting manual, which became popular by means of 'the newest and most systematic and complete edition related to the names of Dionysius of Fourna and Cyril of Chios' (Grecu 1936:34). Dionysius himself had painted, in 1737, closely following the directions of the hermeneia, an icon of the holiday for the Metamorphosis monastery of Sotira, in Fourna.

In the Romanian space, copies after Dionysius' textbook circulated from early times. Of the Greek manuscripts of the Hermeneia, currently preserved in various European collections, the oldest one dates back to 1775 and can be found in the library of the Romanian Academy in Bucharest (Grecu 1936:4). Romanian translations of the same work were also made early, after the Greek variants; the translations for which a certain date is known are the ones from 1805 to 1841 (Grecu 1936:25). The 1805 translation was made by Archimandrite Macarie, in Bucharest (Grecu 1936:32), and the 1841 manuscript is a copy of Dionysius' work, translated from Greek by the monks from the Cozia monastery (Ghenadie 1891:39).

The very detailed instructions contained in the textbook of church painting provided modern painters with a way to represent the scene, which in the Hermeneia was called 'The spring of healing and of life'. We can recognise this new formula in the icons painted on glass by folk craftsmen from Transylvania, an example at hand being that of painter Matei Țâmforea (1836-1906), a native of Cârţişoara village (Sibiu County), who mastered the subject including it in the thematic repertoire of his creations. One of the feast icons assigned to him is kept in a private collection in Făgăraş (Carol Fúlop Szöcs Collection, icon dated 1886) (Dumitran, Szöcs \& Băjenaru 2012:62), while another one is in the patrimony of the Astra National Museum Complex in Sibiu (inv. no. 1130, work dated 1888) (Ionescu 2009:75).

\section{Conclusions}

Adopted from the Byzantine iconographic tradition, in the context of the close relations that the Danube Principalities had with Serbia and Mount Athos, the model of representing the Life-giving Spring stimulated the interpretive ability and creativity of Romanian painters. They assimilated it both in terms of content as well as expression, a fact demonstrated by the proper way of implanting this subject in the mural painting 
ensembles, in accordance with the symbolic functions with which the narthex or the proscomidaire was invested in church architecture. The same full accommodation of the image to a certain context is noticeable in the case of church prints in Transylvania, where the icon illustrates both the subject of the feast itself and, in a more general way, of the Paraklesis to the Most Holy Theotokos. What is ultimately remarkable is not so much the frequency of representation of the theme in Romanian iconography, but the diversity of genres, techniques and means of plastic expression that served to illustrate it, as we find it transposed on a monumental scale by mural painters, in portable icons painted on wood or glass, refined by goldsmiths or impressed on engraving plates.

\section{Acknowledgements Competing interests}

The author declares that he has no financial or personal relationships that may have inappropriately influenced him in writing this article.

\section{Author's contributions}

I.O.A. is the sole author of this article.

\section{Ethical considerations}

This article followed all ethical standards for research without direct contact with human or animal subjects.

\section{Funding information}

This research received no specific grant from any funding agency in the public, commercial or not-for-profit sectors.

\section{Data availability}

Data sharing is not applicable to this article as no new data were created or analysed in this study.

\section{Disclaimer}

The views and opinions expressed in this article are those of the author and do not necessarily reflect the official policy or position of any affiliated agency of the author.

\section{References}

Belting, H., 1994, Likeness and presence: A history of the image before the era of art transl. Edmund Jephcott, The University of Chicago Press, Chicago, IL.

Brisby, C., 2003, 'An icon of Theotokos Zoodohos Pighi - Bogoroditsa Zhivonosen Iztochnik - Mother of God Life-giving Spring: Aspects of later Byzantine Art' Проблеми на изкуство 36(4), 30-44.

Buda, D., 2018, 'Again, about the power of image: A few reflections based on personal experiences and some recent publications', in Making mission from the model of Christ: Iconography and use of image in mission: A historical and missiological approach, pp. 181-188, ASTRA Museum Publishing House, Sibiu.

Buzilă, C., 2010, 'Biserica Mănăstirii Colţea', in Revista Monumentelor Istorice, pp. 1-2, Institutul Naţional al Patrimoniului, Bucureşti.

Cândea, V., 2011, Mărturii românești peste hotare: Creaţii româneşti şi izvoare despre români în colecţii din străinătate: Serie nouă II, Finlanda - Grecia, Editura Biblioteca, Bucureşti.

Cândea, V. \& Simionescu, C., 1982, Prezenţe culturale româneşti: Istambul, lerusalim, Paros, Patmos, Sinai, Alep, Editura Sport-Turism, Bucureşti.
Cojocaru, C., 2015, 'Iconografia pronaosului în bisericile de secol al XVIII-lea din zona Bucuresti-llfov', in V. Bedros \& M. Sabados (eds.), Spicilegium: Studii si articole în onoarea prof. Corina Popa, pp. 161-179, Editura UNArte București.

Constantinou, S., 2021, 'A rewriter at work: Nikephoros Xanthopoulos and the Pege Miracles', in S. Constantinou \& C. Høgel (eds.), Metaphrasis: A Byzantine concept of rewriting and its Hagiographical Products, pp. 324-342, Brill, s.l.

Dinioară, A., 2020, 'Cişmelele lui Mavrogheni', Tezaur: Foaie a Bibliotecii Academie Române, p. 4, Bucureşti.

Dumitran, A., Szöcs, F.K. \& Băjenaru, E., 2012, Icoane pe sticlă din Transilvania Colecţia Szöcs, Editura Altip, Alba lulia.

Dumitrescu, C.L., 1973, 'Programe iconografice în pronaosul bisericilor de mănăstire din Tara Românească în secolul al XVI-lea', in Studii și Cercetări de Istoria Artei: Seria Artă Plastică, vol. 20, no. 3, pp. 257-271, Bucureşti.

Dumitrescu, C.L., 1978, Pictura murală din Jara Românească în veacul al XVI-lea, ed. Meridiane, Bucureşti.

Farcaşiu, L., 2008, 'Sfântul Ioan Damaschin: Personalitatea si opera sa imnografică', Teologia XII(2), 1-243.

Ghenadie, 1891, Iconografia: Arta de a zugrăvi templele şi icoanele bisericești. Manuscris cu o precuvântare, descris şi adnotat de Ghenadi e al. Râmnicului, Tipografia Cărţilor Bisericeşti Bucureşti.

Grecu, V., 1936, Cărţi de pictură bisericească bizantină. introducere şi ediţie critică a versiunilor românești atât după redacțiunea lui Dionisie din Furna tradusă la 1805 de Arhimandritul Macarie cât şi după redacțiuni mai vechi traduceri anonime, Glasul Bucovinei, Cernăuţi.

Hauri, J. \& Wirth, G. (eds.), 1963, Procopii Caesariensis opera omnia, III: De aedificiis, Leipzig, viewed from (English version) http://penelope.uchicago.edu/Thayer/E/ Roman/Texts/Procopius/Buildings/home.html.

lancovescu, I., 2008a, 'Mănăstirea Hurezi. Prezentare generală', in C. Popa, I. lancovescu, E. Negrău \& V. Bedros (eds.), Repertoriul picturii murale brâncoveneşti: Judeţul Vâlcea, pp. 41-45, Editura Unarte, Bucureşti.

Iancovescu, I., 2008b, 'Biserica Sfinţii Împăraţi. Pictura', in C. Popa, I. Iancovescu, E. Negrău \& V. Bedros (eds.), Repertoriul picturii murale brâncoveneşti: Judeţu Vâlcea, pp. 47-54, Editura Unarte, Bucureşti.

Iancovescu, I., 2008c, 'Biserica Adormirea Maicii Domnului a mănăstirii Govora', in C. Popa, I. lancovescu, E. Negrău \& V. Bedros (eds.), Repertoriul picturii murale brâncoveneşti: Judeţul Vâlcea, pp. 349-367, Editura Unarte, Bucureşti.

Ionescu, A.G., 2009, Icoane pe lemn şi sticlă din principalele colecţii sibiene, Astra Museum, Sibiu.

Lubanska, M., 2017, 'Life-giving Springs and the mother of God Zhivonosen Istochnik/ Zoodochos Pege/Balúkliyska: Byzantine-Greek-Ottoman intercultural influence and its aftereffects in iconography, religious writings and ritual practices in the region of Plovdiv', Slavia Meridionalis 17. https://doi.org/10.11649/sm.1252

Majeska, G.P., 1984, Russian travelers to Constantinople in the fourteenth and fifteenth centuries, Dumbarton Oaks Research Library and Collection Washington, District of Columbia.

Mango, C., 1972, 'De sacris aedibus Deiparae ad Fontem, Acta Sanctorum Nov. III, 879', in The art of the Byzantine empire 312-1453: Sources and documents, Prentice-Hall, Inc., Englewood Cliffs, NJ.

Millet, G., 1910, Monuments byzantins de Mistra, Matériaux pour l'étude de l'architecture et de la peinture en Grèce aux XIV et XV siècles, Ernest Leroux (éd), Paris.

Mircea, G., 2008, Tipografia din Blaj în anii 1747-1830, Editura Altip, Alba lulia.

Porumb, M., 1998, Dicţionar de pictură veche românească din Transilvania, sec. XIII-XVIII, Editura Academiei Române, Bucureşti.

Runciman, S., 1971, Căderea Constantinopolului 1453, Traducere de Alexandru Elian, Editura Ştiinţifică, Bucureşti.

Starodubcev, T.A., 2009, 'The cult of the Virgin Zoodochoz pege and its reflection in the painting of the Palaiologan era', Zograf (33), 101-119. https://doi. org/10.2298/ZOG0933101S

Ștefănescu, I.D., 1929, L'Évolution de la peinture religieuse en Bucovine et en Moldavie depuis les origines jusqu'au XIX siècle. Nouvelles recherches. Étude iconographique - Texte, Libraire Orientaliste Paul Geuthner, Paris.

Ştefănescu, I.D., 1932, L'Évolution de la peinture religieuse en Valachie et en Transylvanie depuis les origines jusqu'au XIX siècle.Texte, Libraire Orientaliste Paul Geuthner, Paris.

Tatai-Baltă, C., 1995, Gravorii în lemn de la Blaj (1750-1830), Editura Eventus, Blaj.

Teteriatnikov, N., 2005, 'The image of the Virgin Zoodochos Pege: Two questions concerning its origin', in M. Vassiliaki (ed.), Images of the mother of God: Perceptions of Theotokos in Byzantium, pp. 225-238, Ashgate, Farnham.

Tsiouris, I., 2013, 'Artistic trends and aesthetic approaches in 18th century monumental painting: The case of Thessaly', Проблеми на изкуството, pp. 1825, София.

Ulea, S., 1964, 'Gavriil ieromonahul - Autorul frescelor de la Bălineşti: Introducere la studiul picturii moldoveneşti din epoca lui Ştefan cel Mare', in M. Berza (ed.), Cultura moldovenească în timpul lui Ştefancel Mare, pp. 420-424, ed. Academiei, Bucureşti.

Ullea, S., 2012, Încheierea cronologiei picturii moldovenești secolele XV-XVI cu datarea ansamblurilor de la Părhăuţi şi Arbure, Editura Muşatina, Roman.

Vasiliu, A., 1991, 'Un model de iconografie monastică de la începutul veacului al XVIII-lea', in Studii şi Cercetări de Istoria Artei, Seria Artă Plastică, p. 38 Universul, Bucureşti.

Vintilescu, P., 2006, Despre poezia imnografică din cărtile de ritual si cântarea bisericească, Editura Partener, Galaţi. 